Journal of Agricultural Sciences
(Tarim Bilimleri Dergisi)

\title{
Stabilities of Some Local Pea Lines
}

\author{
Reyhan KARAYEL ${ }^{\text {a*D }}$, Hatice BOZOĞLU ${ }^{b}(\mathbb{D}$ \\ $\boldsymbol{a}_{\text {The Black Sea Agriculture Research Institute, Samsun, TURKEY }}$ \\ ${ }^{b}$ University of Ondokuzmayls, Faculty of Agriculture, Samsun, TURKEY
}

\section{ARTICLE INFO}

Research Article

Corresponding Author: Reyhan KARAYEL, E-mail: reyhan.karayel@tarimorman.gov.tr

Received: 14 August 2020 / Revised: 02 December 2020 / Accepted: 02 December 2020 / Online: 20 January 2022

\section{ABSTRACT}

This study was conducted to determine the stabilities and adaptation classes of edible pea lines, which will be cultivated in mild climate regions. Twenty local pea lines selected in previous breeding studies and 6 control varieties were used. The seeds of pea lines were sowed in 4 different locations in 2 sowing times. The experiment was conducted according to the Augmented design. Adaptation classes and stabilities of pea lines and varieties were determined based on fresh pod yield, fresh seed yield and dry seed yield. The mean of fresh pod yield was found as $1185.7 \mathrm{~kg} \mathrm{da}^{-1}$. Stable variety was not determined in terms of fresh pod yield among control varieties, which was conducted in the conclusion of evaluation as determining regression coefficient and average reliability.

Keywords: Pea, Stability, Yield, Adaptation classes
The average of varieties' fresh seed yield was $693.8 \mathrm{~kg} \mathrm{da}^{-1}$, Klein variety showed medium adaptation for all regions. It was found that 3 lines $\left(B_{15}\right.$, $\mathrm{B}_{33}$, and $\mathrm{B}_{36}$ ) among used ones were placed at the same statistically group with this variety. The average of dry seed yield was $267.1 \mathrm{~kg} \mathrm{da}^{-1}$ in the experiment, and Klein, Further, Green Pearl, and Lancet varieties were identified as stable varieties in the conclusion of stability analysis. $\mathrm{B}_{6}, \mathrm{~B}_{13}$, $\mathrm{B}_{14}, \mathrm{~B}_{15}, \mathrm{~B}_{16}, \mathrm{~B}_{17}, \mathrm{~B}_{18}, \mathrm{~B}_{32}, \mathrm{~B}_{40}$ and $\mathrm{B}_{42}$ lines that involved in the same statistically group with these varieties identified were as stable. In the conclusion of the overall evaluation of the experiment, it was found that $\mathrm{B}_{6}$ and $\mathrm{B}_{32}$ lines could be candidates for variety.

(C) Ankara University, Faculty of Agriculture

\section{Introduction}

Pea is one of the most commonly used edible grain legumes. Thus, studies have been extensively carried out to investigate several aspects of pea cultivars in all over the world. Fresh pods and seeds of peas are used as fresh, frozen or canned vegetable and dry seeds or whole plant is used as forage (Akçin 1988). In addition, recently in the USA and also in many countries, the pea is used as modernist bakery products such as functional food, protein concentrates (55-60\% protein) and isolates (85\% protein), and as protein, folate and mineral enhancer in bread, pasta, cereals for breakfast, biscuits, crackers, energy bars, pressed cookies and processed meat products (URL-1). The largest cultivation of pea in the world takes place in Canada, where has the largest cultivation area in the world. In Canada, the pea is used for making bread because of due to the fiber-rich ingredient. The protein extracted from pea is used consumed as alternative source of protein by for the people who have soybean allergy as alternative source of protein and to enrichment of the animal rations. The cellulose of pea is used for fermented sausage and breakfast cereals and confectionery because of the swelling and water holding characteristics. In addition, pea starch is used in thickener, adhesive and carbon paper productions (Ratnayake et al. 2001). According to FAO 2018 statistics, dry pea cultivation area was 7.8 million ha, its yield was $171.8 \mathrm{~kg} \mathrm{da}^{-1}$ and fresh pea cultivation area was 2.7 million ha, the yield was $773.6 \mathrm{~kg} \mathrm{da}^{-1}$ in the world in 2018. The agriculture of pea is not widespread like chickpea, lentil and bean in Turkey. In Turkey, cultivation area of dry pea is $907 \mathrm{ha}$, production amount is 2603 tons, average yield is $287.0 \mathrm{~kg} \mathrm{da}^{-1}$; vegetable pea cultivation area is 10917 ha, production amount is 107344 tons, the average yield is $983.2 \mathrm{~kg} \mathrm{da}^{-1}$ for fresh consumption. According to these statistics, Turkey takes the last ranks among countries, which cultivate pea. However, Anatolia, one of the origin centers of the pea, has suitable ecological conditions for pea cultivation. Pea agriculture becomes intense in the areas where are food industry regions in Turkey and its agriculture is maintained with Northern European countries varieties. In addition, local pea varieties were cultivated in the small family farms located in coastal regions with mild climate. Development of new varieties and determining the characteristics of local varieties are important to expand the pea cultivation. The environmental characteristics of a region and genotypic factors have significant impacts on yield performances of pea genotypes. Therefore, long-term studies should be conducted in several regions with different environmental characteristics. In these studies, both the differences between genotypes and genotype $\mathrm{x}$ environment interactions which come up because of showing different reactions of genotypes in different environments are analyzed. 
The main objectives of plant breeding studies are developing highly productive varieties and making the new varieties available for producers. Therefore, studies primarily focused to develop advanced pea lines and determine the promising characteristics. The data obtained in these studies reveal the information on performances of varieties under different environmental conditions, and the findings are evaluated using specific statistical methods.

Stability analyses are applied to choose genotype when genotype $\mathrm{x}$ environment interactions indicated by variance analysis are significant. Stability is defined as to estimates of a change in environmental conditions, potential effects on genotypes (Kafa and Kirtok 1991). Becker (1981) defined biological stability as varieties showing a stable yield in different environments and as to agricultural stability as varieties in a certain environment has the specified level of efficiency in that environment. If genotype $\mathrm{x}$ environmental interactions are significant, the breeder should determine genotypes that do not show much variability in their productivity under changing environmental conditions, that is to say stable genotypes (Bozoğlu and Gülümser 2000).

Expansion of pea cultivation in our country as in developed countries of the world will make a significant contribution to food processing industry and agriculture. The most important duty of a breeder or an agronomist is to support this projection by ensuring the sustainability of local materials and developing new varieties suitable for the different regions of the country.

The pea is an important legume that can be used in crop rotation and sown as a winter crop in mild climate regions. Therefore, this study aimed to determine the stabilities of edible variety pea candidates, which have been determined as lines by choosing among local pea populations.

\section{Material and Methods}

The study was conducted in 8 different environments (Amasya, Samsun-Atakum, Samsun-Gelemen and, Tokat in 2 different sowing times winter and early spring) during 2015 and 2016. Some of the climatic data belonged to the environments where the experiments were carried out were presented in Figure 1 and 2. The data indicated that climates of Amasya and Tokat, Gelemen and Atakum are similar.

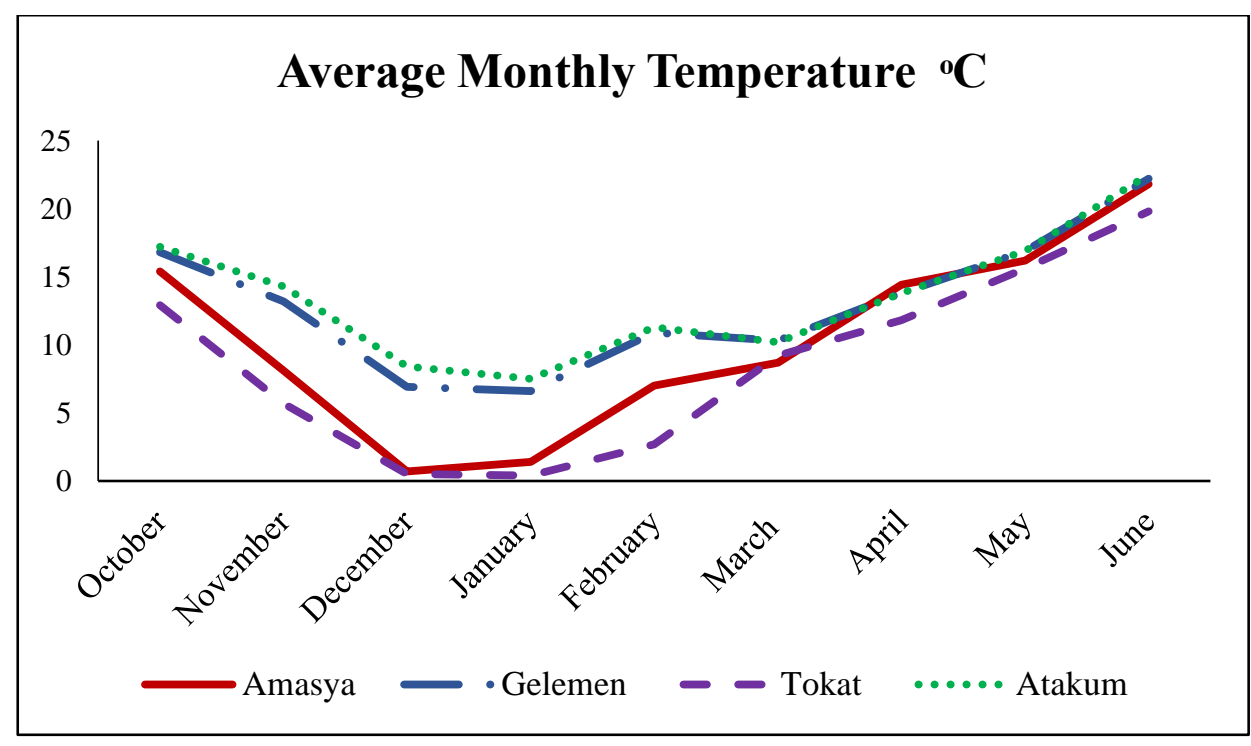

Figure 1- 2015-2016 temperature values in the locations where experiments are carried out 


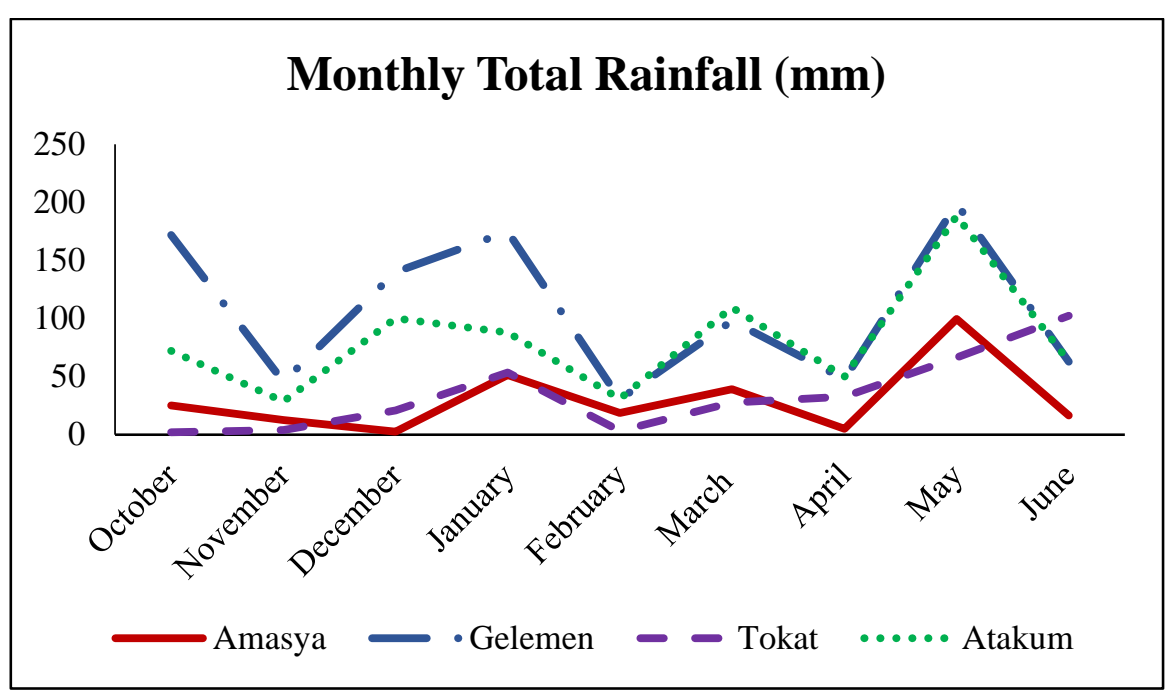

Figure 2- 2015-2016 rainfall values in the locations where experiments are carried out

Some differences were found out for the environments' soil characteristics. When Table 1 is analyzed, it is understood that insignificant variations were seen for soil type, $\mathrm{pH}$ and salinity, whereas there was no variation for potassium among regions. Significant variations were seen for lime and organic substance at other characteristics.

Table 1- Analysis results of soil properties of trial areas

\begin{tabular}{lllll}
\hline Properties & Amasya & Samsun-Gelemen & Samsun-Atakum & Tokat \\
\hline Saturation \% & Clayey loam & Clayey loam & Clayey & Clayey loam \\
pH & Neutral & Slightly alkaline & Neutral & Slightly alkaline \\
Lime $\left(\mathrm{CaCO}_{3}\right)$ & High limy & Very low limy & Limy & Middle limy \\
$\%$ Total Salt \% & Unsalted & Unsalted & Slightly salty & Unsalted \\
Phosphorus $\left(\mathbf{P}_{2} \mathbf{O}_{5} \mathbf{~ k g ~ d a}^{-1}\right)$ & Very high & Very high & Low & Very low \\
Potassium $\left(\mathrm{K}_{\mathbf{2}} \mathrm{O} \mathrm{kg} \mathrm{da}^{-1}\right)$ & High & High & High & High \\
Organic matter \% & Low & Low & Low & Very low \\
\hline
\end{tabular}

In the study 20 lines selected fresh and dry seed purpose fully with selection breeding among local pea materials (Karayel and Bozoğlu 2008) and 6 control varieties (Green Pearl, Sprinter, Further, Vilmoren, Lancet, and Klein) were used.

The experiments were carried out according to the Augmented Design in which the control varieties were placed in 3 blocks, and the lines were randomly placed in 3 blocks. The seeds of control varieties were sown at $60 \mathrm{~cm}$ row spacings on 4 rows with $4 \mathrm{~m}$ length, while the lines were sown on 2 rows at the same row spacings. The sowing dates for winter and early spring were given in Table 2. The experiments were carried out under rainfed conditions. Weed control was performed by hoeing when necessary. The pea was harvested as fresh and dry to determine the candidate varieties. The fresh and dry harvest dates were given in Table 2. Statistical analysis was carried out using SPSS software. Stability analyses were used to control varieties with regression model as Eberhart-Russell (1966) suggested and adaptation classes were applied as Arshad (1990) suggested. Varieties that average was higher than general average, regression coefficient (b) was equal to 1 , regression deviation $\left(S^{2}\right.$ b) variance was 0 or near 0 were defined as stable. Genotypes adaptation classes were defined as using experiments' general average $(\bar{x})$, regression coefficient (bi) and confidence limits (G.S $=\bar{x} \pm t . S$ x) determined for it (Bozoğlu \& Gülümser 2000). These parameters were determined for control varieties, because Augmented Design was used for our experiment and at this design, only the control varieties values' variance analyses were done. The adaptation classes of control varieties and the lines those were placed at the same static group were decided regarding $5 \%$ probability with LSD test grouping in the conclusion of variance analyses.

Table 2- Sowing dates and harvest date ranges of experiments

\begin{tabular}{lcccc}
\hline \multicolumn{1}{c}{ Location } & Winter sown date & Early spring sown date & Fresh harvest dates & Dry harvest dates \\
\hline Samsun-Gelemen & 04.11 .2015 & 04.03 .2016 & $18.05 .-01.06 .2016$ & $20.06-30.06 .2016$ \\
Samsun-Atakum & 20.11 .2015 & 03.03 .2016 & $20.05-18.06 .2016$ & $13.06-25.06 .2016$ \\
Amasya & 28.10 .2015 & 09.03 .2016 & $20.05-17.06 .2016$ & $16.06-24.06 .2016$ \\
Tokat & 05.11 .2015 & 02.03 .2016 & $15.04-27.05 .2016$ & $20.05-17.06 .2016$ \\
\hline
\end{tabular}




\section{Results and Discussion}

Pea is a cool season legume plant. Total temperature demand of peas is $1600-2800{ }^{\circ} \mathrm{C}$ for full maturity; generally, it is sowed in autumn in mild climate regions, though it is sowed in early spring in regions where the winter is spent hard. Experiments were established in the same environment in two different planting times (winter and early spring) to create a different environment. Experiments were carried out at 8 environments with 6 control varieties and 30 lines. Their yield values and averages belonging to parameters required for stability and statistical grouping were given at Table 3 .

Table 3- Stability parameters of yield values of pea genotypes grown in different environments

\begin{tabular}{|c|c|c|c|c|c|c|c|c|c|}
\hline Genotypes & $\begin{array}{c}\text { FPY } \\
\left(\mathbf{k g ~ d a}^{-1}\right)\end{array}$ & $\begin{array}{l}\text { RC } \\
\text { (bi) }\end{array}$ & $\begin{array}{c}\text { DR } \\
\left(\mathbf{S}^{2} \mathbf{d}\right)\end{array}$ & $\begin{array}{c}\text { FSY } \\
\left(\mathbf{k g ~ d a}^{-1}\right)\end{array}$ & $\begin{array}{l}\text { RC } \\
\text { (bi) }\end{array}$ & $\begin{array}{c}\text { DR } \\
\left(\mathbf{S}^{2} \mathbf{d}\right)\end{array}$ & $\begin{array}{c}\text { DSY } \\
\left(\mathbf{k g ~ d a}^{-1}\right)\end{array}$ & $\begin{array}{l}\text { RC } \\
\text { (bi) }\end{array}$ & $\begin{array}{r}\text { DR } \\
\left(\mathbf{S}^{2} \mathbf{d}\right)\end{array}$ \\
\hline G. Pearl & $1155.8 \mathrm{de}$ & 0.52 & 156012 & $682.2 \mathrm{~cd}$ & 0.40 & 62292 & $281.3 \mathrm{abc}$ & 1.10 & 2266 \\
\hline Sprinter & $1359.5 \mathrm{~cd}$ & 1.95 & 219404 & $695.8 \mathrm{~cd}$ & 1.31 & 84656 & $313.8 \mathrm{a}$ & 1.7 & 2903 \\
\hline Further & $1017.9 \mathrm{~d}-\mathrm{h}$ & 0.78 & 126933 & $570.7 \mathrm{e}-\mathrm{h}$ & 0.42 & 28322 & $263.9 \mathrm{~b}-\mathrm{e}$ & 1.01 & 4281 \\
\hline Vilmoren & $986.4 \mathrm{dfg}$ & 0.42 & 68844 & $744.4 \mathrm{c}$ & 1.11 & 28867 & $205.7 \mathrm{~g}-\mathrm{j}$ & 0.1 & 3293 \\
\hline Lancet & $1503.5 \mathrm{bc}$ & 1.39 & 347737 & 788.6 bc & 1.78 & 115909 & $306.8 \mathrm{ab}$ & 1.12 & 5068 \\
\hline Klein & $1091.3 \mathrm{df}$ & 0.94 & 43318.3 & 681.0 cde & 0.97 & 892.4 & $231.3 \mathrm{c}-\mathrm{j}$ & 0.97 & 7387 \\
\hline Mean & 1185.7 & 1 & & 693.8 & 1 & & 267.1 & 1 & \\
\hline CL & $\mathrm{X} \pm 83.44$ & $\mathrm{X} \pm 0.24$ & & $\mathrm{X} \pm 77.1$ & $\mathrm{X} \pm 0.28$ & & $\mathrm{X} \pm 44.56$ & $X \pm 0.54$ & \\
\hline B1 & $759.4 \mathrm{ij}$ & & & $410.3 \mathrm{ij}$ & & & 206.9 h-k & & \\
\hline B3 & $756.7 \mathrm{ij}$ & & & $471.4 \mathrm{hi}$ & & & $219.4 \mathrm{f}-\mathrm{j}$ & & \\
\hline B6 & $1734.3 \mathrm{a}$ & & & 975.9 a & & & 320.9 a & & \\
\hline B10 & $811.5 \mathrm{hij}$ & & & $490.1 \mathrm{~g} \mathrm{hi}$ & & & $243.4 \mathrm{jk}$ & & \\
\hline B11 & $751.7 \mathrm{ij}$ & & & $484.6 \mathrm{ghi}$ & & & $271.7 \mathrm{f}-\mathrm{j}$ & & \\
\hline B13 & $782.8 \mathrm{~h} \mathrm{ij}$ & & & $398.2 \mathrm{ij}$ & & & $170.4 \mathrm{jk}$ & & \\
\hline B14 & $703.9 \mathrm{j}$ & & & $314.0 \mathrm{j}$ & & & $209.1 \mathrm{~d}-\mathrm{j}$ & & \\
\hline B15 & $1057.0 \mathrm{df}$ & & & $535.5 \mathrm{fgh}$ & & & $295.5 \mathrm{a}-\mathrm{d}$ & & \\
\hline B16 & 769.0 hij & & & $408.0 \mathrm{ij}$ & & & $223.1 \mathrm{e}-\mathrm{j}$ & & \\
\hline B17 & $642.1 \mathrm{j}$ & & & $376.6 \mathrm{ij}$ & & & $287.1 \mathrm{c}-\mathrm{h}$ & & \\
\hline B18 & $695.0 \mathrm{j}$ & & & $405.4 \mathrm{ij}$ & & & $248.9 \mathrm{~b}-\mathrm{f}$ & & \\
\hline B19 & $784.0 \mathrm{hij}$ & & & $410.1 \mathrm{ij}$ & & & $290.0 \mathrm{hij}$ & & \\
\hline B32 & $1587.6 \mathrm{ab}$ & & & $868.0 \mathrm{ab}$ & & & $298.9 \mathrm{c}-\mathrm{i}$ & & \\
\hline B33 & 909.9 e-i & & & $548.5 \mathrm{fgh}$ & & & $211.2 \mathrm{~d}-\mathrm{jj}$ & & \\
\hline B34 & 787.9 hij & & & $595.3 \mathrm{~d}-\mathrm{g}$ & & & $241.7 \mathrm{ij}$ & & \\
\hline B35 & $731.7 \mathrm{j}$ & & & $401.4 \mathrm{ij}$ & & & $204.7 \mathrm{jk}$ & & \\
\hline B36 & $945.3 \mathrm{e}-\mathrm{i}$ & & & $551.0 \mathrm{fgh}$ & & & $232.3 \mathrm{~h}-\mathrm{k}$ & & \\
\hline B40 & $688.8 \mathrm{j}$ & & & $558.1 \mathrm{fgh}$ & & & $311.6 \mathrm{a}$ & & \\
\hline B41 & $756.8 \mathrm{ij}$ & & & $331.5 \mathrm{j}$ & & & 241.5 h-k & & \\
\hline B42 & $969.6 \mathrm{~d}-\mathrm{i}$ & & & $533.4 \mathrm{fgh}$ & & & $247.7 \mathrm{~d}-\mathrm{j}$ & & \\
\hline LSD & 205.1 & & & 116.4 & & & 49.8 & & \\
\hline
\end{tabular}

RC: Regression Coefficient (bi); DR: Deviation from Regression (S²d); CL: Confidence Limits; FPY: Fresh Pod Yield; FSY: Fresh Seed Yield; DSY: Dry Seed Yield, LSD: Least Significant Difference

\subsection{Fresh pod yield}

Pea is consumed as fresh seed, and sold with pods at local public markets in Turkey. Thus, the freshness of seeds after the harvest can conserve for a while. Therefore, the pod yield should also be determined. Since no graining is needed, the unit price is low. In our study, the average of fresh pod yield was $1185.7 \mathrm{~kg} \mathrm{da}^{-1}$, and as control varieties Sprinter and Lancet had higher values than the overall average. Regression coefficient of Lancet variety was nearer to 1. Sprinter and Lancet showed well adaptation to good environmental conditions as it can be seen from the stability graphic (Figure 3) given for fresh pod yield. The assessment conducted with mean confidence intervals and regression coefficients obtained using the fresh pod yield among the control varieties indicated no stable variety. Murtaza et al. (2007) stated fresh pod yield for pea was $276.7-525.5 \mathrm{~kg} \mathrm{da}^{-1}(318.9 \mathrm{~kg} \mathrm{da}$

${ }^{1}$ in control) for salicylic acid applications on pea seeds and leaves in Pakistan; Alam et al. (2010) stated it was 584.0 - 1144.0 
$\mathrm{kg} \mathrm{da}^{-1}$ for different fertilizer grade applications on pea in Bangladesh; Rasaei et al. (2012) stated it was 430.0- 910.0 kg da ${ }^{-1}$ for different irrigation dates and frequencies on pea in Iran; Gopinath and Mina (2011) stated it was 220.0- 724.0 kg da-1 for organic fertilizer applications on pea in India. According to the conclusion of multiple range test (LSD), it was found that $\mathrm{B}_{6}(1734.3 \mathrm{~kg}$ $\mathrm{da}^{-1}$ ) and $\mathrm{B}_{32}$ (909.9 $\mathrm{kg} \mathrm{da}^{-1}$ ) were placed at the same group with Lancet variety which showed well adaptation to good environmental conditions among 20 lines that was used (Table 2).

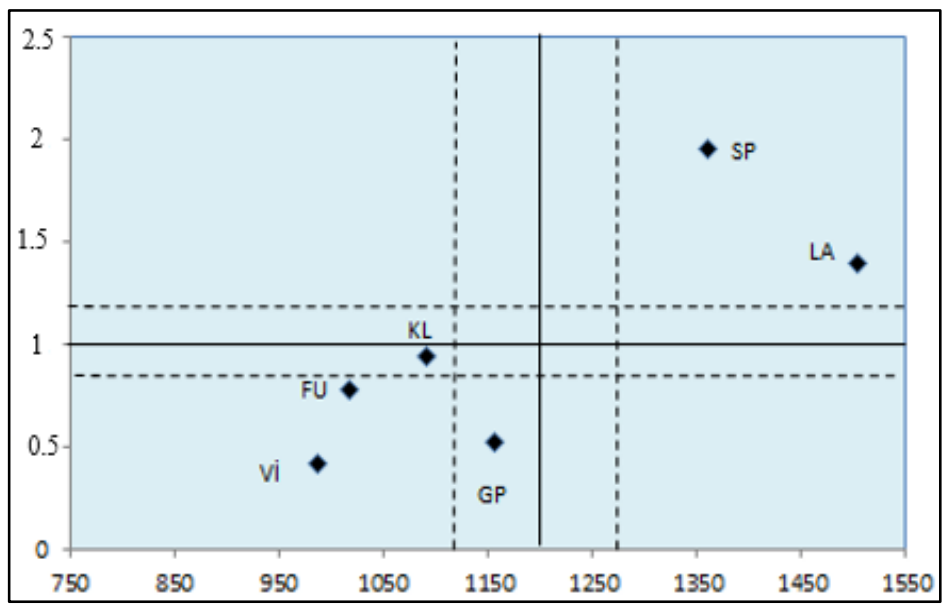

Figure 3- Stability graph of fresh pod yield of pea varieties

\subsection{Fresh seed yield}

Fresh pea seed is consumed both as fresh to cook directly and mostly canned in Turkey. The fresh seed yield was significantly different between genotypes and changed depending on the harvest dates. The seeds were lighter in early harvest, whereas peel pod was thinner and seed weight was heavier in the late harvest due to carbohydrate accumulation. Kalapchieva and Pevicharova (2009) reported that fresh seed yield ranged between 253.2 and $618.0 \mathrm{~kg} \mathrm{da}^{-1}$ in 2000 and 2004 for Marsi variety, which is a new variety in Bulgaria. The difference in yield values can be attributed to the differences in the genotypes used and the growing environments. In our study, mean fresh seed yield for control varieties was $693.8 \mathrm{~kg} \mathrm{da}^{-1}$. The mean yield of Sprinter, Vilmoren and Lancet varieties was higher than the overall average yield value (Table 2). $\mathrm{B}_{6}$ line gave the highest fresh seed yield as 975.9 $\mathrm{kg} \mathrm{da}^{-1}$ among lines. It was determined that control varieties were different from that line statistically. $\mathrm{B}_{32}$ line came after $\mathrm{B}_{6}$ with $868.0 \mathrm{~kg} \mathrm{da}^{-1}$ fresh seed yield. That line placed at the same statistic group with Lancet which showed well adaptation to good environmental conditions (Figure 4). Calculated confidence limit for the average of experiment's fresh seed yield changed between $616.7-770.9 \mathrm{~kg} \mathrm{da}^{-1}$. Klein and Vilmoren showed medium adaptation to all environments, it was found that they were the most stable varieties namely. Only one line $\left(\mathrm{B}_{34}\right)$ placed at the same group with those varieties statistically.

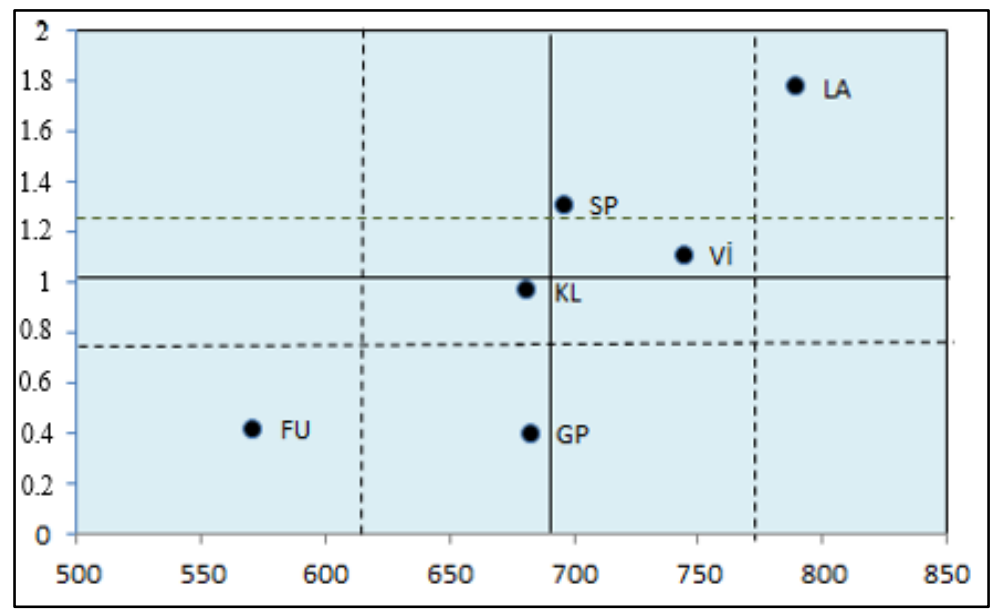

Figure 4- Stability graph of fresh seed yield of pea varieties

It was found that Klein and Vilmoren showed medium adaptation to all environments, namely stable, Lancet showed well adaptation to good environmental conditions, Green Pearl showed medium adaptation to bad environmental conditions. Among the lines only $\mathrm{B}_{34}$ line placed at the same statistic group with these varieties, and it was determined as stable line in terms of fresh seed. 


\subsection{Dry Seed Yield}

High protein content of edible legumes consumed as dry seed come into prominence. Dry seed yield is an important trait even if pea is not consumed as dry seed. Various dry seed yields have been reported in studies conducted different ecological regions of Turkey. Öz \& Karasu (2010) reported dry seed yield between 96.8 and $149.0 \mathrm{~kg} \mathrm{da}^{-1}$ under ecological conditions of Bursa province, and the dry seed yield in İzmir ecology was between 143.0 and $349.0 \mathrm{~kg} \mathrm{da}^{-1}$ (Alan \& Geren 2012). The dry seed yield under Ankara ecology ranged from 190.9 to $276.4 \mathrm{~kg} \mathrm{da}^{-1}$ (Kara \& Ünver 1999). Dry seed yield recorded in this study was 267.1 $\mathrm{kg} \mathrm{da}^{-1}$, which was higher than the dry seed yields reported in literature and mean value in Turkey. Bozoğlu et al. (2007) found that dry seed yield was $212.4 \mathrm{~kg} \mathrm{da}^{-1}$ averagely for winter sowing and $164.6 \mathrm{~kg} \mathrm{da}^{-1}$ for in summer sowing in their study with 15 genotypes under Samsun's conditions. It was stated that Vilmoren and Sprinter placed at the first lines particularly in winter sowings. Except Vilmoren and Sprinter, all other control varieties were between confidence limit $\left(222.54-311.66 \mathrm{~kg} \mathrm{da}^{-1}\right)$ that is determined $\mathrm{P}<0.05$ probability. This limit changed between $0.46-1.54$ for regression coefficient. In this case Klein, Further, G. Pearl, and Lancet showed medium adaptation to all environments in terms of dry seed yield, namely they became stable varieties (Figure 5). It was found that all lines placed at the same group with stable varieties regarding applied LSD grouping.

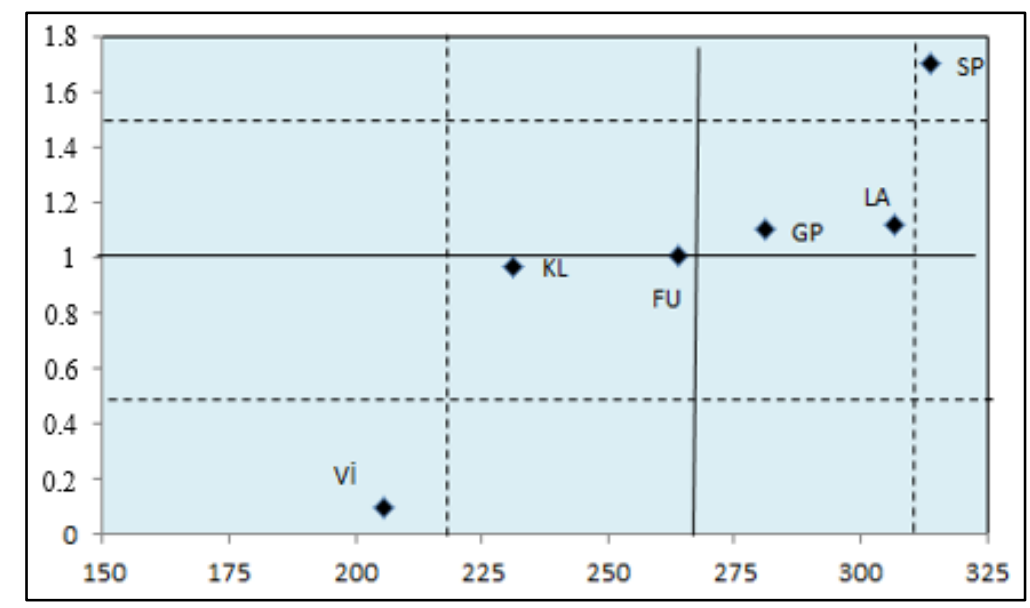

Figure 5- Stability graph of dry seed yield of pea varieties

\section{Conclusions}

The problem of coronavirus disease (COVID-19) that whole world threaten indicated the importance of health to all human being, and emphasized the necessity of living compatible with nature and sustainable use of natural sources. Seed is the most important and non-replaceable input of agricultural production. Domestic seeds, exist for hundreds of thousands of years in a geography are the most valuable sources of modern agriculture. Turkey is one of the germplasm centers of the pea. The aim of this study was determine the pea variety candidates by identifying the adaptation classes and the stabilities of local pea lines determined by the long-term field studies based on the yield characteristics. The experimental was carried out according to the Augmented design with 6 control varieties and 20 lines. Stability analyses were applied for control varieties. The data obtained in stability analysis were interpreted using LSD.

Although adaptation classes were same based on the regression coefficient the deviation, and the confidence limits for dry seed yield, it was found that multiple range test groups were different. It showed that lines and control varieties should be repeated as equal numbers, and a common stability parameter should be determined to make stabilities come up more precise.

The experiments carried out in 8 different environments indicated that the mean fresh pod yield, fresh seed yield and dry seed yield were $1188.7,693.8$ and $267.1 \mathrm{~kg} \mathrm{da}^{-1}$, respectively. Fresh pod and seed yield of $\mathrm{B}_{6}$ and $\mathrm{B}_{32}$ lines were higher than those obtained from control pea varieties. The dry seed yield of $\mathrm{B}_{6}, \mathrm{~B}_{15}, \mathrm{~B}_{32}$ and $\mathrm{B}_{40}$ lines exceeded the overall average dry seed yield. The stability analysis revealed that $\mathrm{B}_{6}$ and $\mathrm{B}_{32}$ lines are stable in terms of fresh pod and seed yield. Klein, Further, Green Pearl and Lancet varieties and $\mathrm{B}_{6}, \mathrm{~B}_{13}, \mathrm{~B}_{14}, \mathrm{~B}_{15}, \mathrm{~B}_{16}, \mathrm{~B}_{17}, \mathrm{~B}_{18}, \mathrm{~B}_{32}, \mathrm{~B}_{40}$ and $\mathrm{B}_{42}$ lines are stable for dry seed yield. Although some licensed varieties are available for the production of fresh seed in Turkey, no licensed local varieties are available for the production dry seed. The results of this study concluded that $\mathrm{B}_{6}$ and $\mathrm{B}_{32}$ lines could be considered as the variety candidates in terms of yield parameters obtained.

\section{Acknowledgements}

The authors thank the TUBITAK for the financial support (Project number: 2140021) 


\section{References}

Akçin A (1988). Legume Crops. Selcuk University Publication 43. Agriculture Faculty Publication: 8. 377 p. Konya (in Turkish)

Alam M K, Uddin M M, Ahmed M, Latif M A \& Rahman M M (2010). Growth and green pod yield of garden pea varieties under different nutrient levels. J. Agrofor. Environ 4(1): 105-107. ISSN 1995-6983

Alan Ö \& Geren H (2012). Effects of different sowing dates on the seed yield and some other agronomical characteristics of pea (Pisum sativum L.). Ege University Agriculture FacultySciences 49(2): 127-134. ISSN 1018 - 8851, e-ISSN 2548-1207

Arshad Y (1990). Some stability parameters used to determine the adaptability of genotypes. Unpublished Master of Science Thesis. Ege University, Science Institute, Field Crops Major Science, Bornova-Izmir, (in Turkish)

Becker H C (1981). Correlations among some statistical measures of phenotypic stability. Euphytica 30: 835-840. https://doi.org/10.1007/BF00038812

Bozoğlu H \& Gülümser A (2000). Determination of genotype x environment interactions of some agronomic characters in dry bean (Phaseolus vulgaris L.) Turkish Journal Agricultural and Forestry 24: 211-220. TUBİTAK, ISSN: 1300-011X / 1303-6173, (in Turkish)

Bozoğlu H, Pekşen E, Pekşen A \& Gülümser A (2007). Determination of the yield performance and harvesting periods of fifteen pea (Pisum sativum L.) cultivars sown in autumn and spring. Pak. J. Bot. 39(6): 2017-2025. DOİ 10.17660/ActaHortic.2002.579.52

Comstock R E \& Moll R H (1963). Genotype-environment interactions. In: Statistical Genetics and Plant Breeding. NAS-NRC. Publ. 982. pp. $164-196$

Eberhart S A \& Russell W A (1966). Stability parameters for comparing varieties. Crop Sci. 6: 36-40. https://doi.org/10.2135/cropsci1966.0011183X000600010011x

FAO (2018) http://www.fao.org/faostat/en/\#data/QC. Last access date: 24.06 .2020

Gopinath K A \& Mina B L (2011). Effect of organic manures on agronomic and economic performance of garden pea (Pisum sativum) and on soil properties. Indian Journal of Agricultural Sciences 81(3): 236-9. http://epubs.icar.org.in/ejourna

Kafa I \& Kırtok Y (1991). Çukurova koşullarında on yazlık buğday çesidinin genotipxçevre interaksiyonları ve adaptasyon yetenekleri üzerine arastırmalar. Çukurova Üniv. Zir. Fak. Dergisi 5(2): 51-61 (in Turkish)

Kalapchieva S \& Pevicharova G (2009). Marsi - a new pea (Pisum sativum L.) variety for freezing. Genetics and Breeding 38(3-4): 73-78

Kara K \& Ünver S (1999). The effects of different row spacing and nitrogen doses on yield and yield components in pea (Pisum sativum L). Journal of Field Crops Central Research Institute 1(2): 36-45. ISSN 132-4310, (in Turkish).

Karayel R \& Bozoğlu H (2008). Some agronomic properties of local pea population collected from different areas of Turkey. Ondokuz Mayis Univ. Agriculture Faculty Sciences 23(1): 32-38. e-ISSN: 1308-8769, (in Turkish)

Murtaza G, Asghar R, Ahmad S \& Majid S A (2007). The yield and yield components of pea (Pisum sativum L.) as influenced by salicylic acid. Pak. J. Bot. 39(2): 551-559. ISSN: 2070-3368

Öz M \& Karasu A (2010). Determination Of Seed Yield and Yield Components of Some Pea (Pisum sativum L) Cultivars. Süleyman Demirel University, Journal of the Faculty of Agriculture 5(1): 44-49. ISSN 1304-9984, e-ISSN: 2687-3419 (in Turkish)

Rasaei A, Ghobadi M E \& Ghobadi M (2012). Effect of supplemental irrigation and plant density on yield and yield components of peas (Pisum sativum L.) in Kermanshah region. African Journal of Agricultural Research 7(15): 2353-2358. DOI: 10.5897/AJAR

Ratnayake W S, Hoover R, Shahidi F, Perera C \& Jane J (2001). Composition, molecular structure, and physicochemical properties of straches from four field pea (Pisum sativum L.) cultivars. Food Chemistry 74: 189-202. DOI 10.1016/S0308-8146(01)00124-8

Tugay M E \& Y1lmaz G (1994). Various environmental interactions in potato. Field Crops Congress, 25-29 April, İzmir, Plant Breeding Proceedings 2: 145-149. (in Turkish).

URL-1. USA Dry Pea \& Lentil Council. Processing Information \& Technical Manual. http://www.pealentil.com/core/files/pealentil/uploads/files/Chapter1.pdf, Last access date: 21.7.2014

(C) 2022 by the author(s). Published by Ankara University, Faculty of Agriculture, Ankara, Turkey. This is an Open Access article distributed under the terms and conditions of the Creative Commons Attribution (CC BY) license (http://creativecommons.org/licenses/by/4.0/), which permits unrestricted use, distribution, and reproduction in any medium, provided the original work is properly cited. 